THURSDAY, APRIL I2, I877

\section{THE ARCTIC BLUE-BOOK}

$\mathrm{T}^{\mathrm{H}}$ admirably illustrated volume which has just appeared in this uninviting form, tells a tale of adventures as interesting and heroic as anything in the long record of Arctic discovery. It throws little light on the question to which public attention has been too much directed this winter - whether any of the misfortunes of the expedition were due to the officers who started the sledge $p$ arties without adequate supplies of limejuice. The report of the Scurvy Committee will appear in a few days. In the mean time it is clear that every pound weight on the sledges was calculated with the utmost care; that wherever anything was to be used in a fluid state an adequate corresponding supply of fuel needed to be carried; that none of the officers, judging from the experience of previous sledge expeditions, seem to have anticipated scurvy; and above all that the work of all the parties on and at the edge of the hitherto untrodden Palæocrystic sea proved so frightfully severe that if lime-juice in abundant rations had been taken the sufferings of the men would probably have been only mitigated. It is to the severity of the work, not to the absence of limejuice, that we believe the terrible outbreaks of scurvy which crippled the sledging parties to have been really due. In Commander Markham's Journal, written on the spot a month out from the ship, he says, "The invalids are not improving, and we are inclined to believe that they are all attacked with scurvy, though we have not been led to suppose that there is any probability of our being so afficted and are ignorant of the symptoms." Swollen knees and ankles are of frequent occurrence in all Arctic sledging expeditions, and they were prepared to expect as much. Scurvy had scarcely been thought of, and the fact that it had not been thought of by officers whose lives and the lives of their men depended on their forethought, and who had studied the experience of their predecessors with anxious care, is sufficient to show that, a priori, there was little or no probability of its appearance. After the experience of Markham's, Aldrich's, and Beaumont's parties, no future travellers over the "Palæocrystic" will omit their lime-juice, but these officers seem all to have been unprepared for scurvy. Aldrich says in his journal, 38th day out :-

"The men are nearly all suffering a great deal with their unfortunate legs, which appear to get worse every day. This we all feel to be very disappointing, as it affects the journey, and although stiff limbs were expected, everyone thought the stiffness would wear off in time. It seems, however, inclined to hang on, and sets at defiance all the limited medical skill we possess among us, and to scorn succumbing to turpentine liniment, bandages, good 'elbow grease,' \&c. With regard to bandages, I am almost afraid to apply them, for some of the limbs are not at all healthy looking; the slightest pressure of the finger leaves a dent which remains a considerable time; and although I have given the most stringent orders about lacing the foot gear on very slackly, I find the loosest moccasin string cuts an ugly, red-looking mark. One or two cannot even bear anyone to lie against them, which makes it excessively inconvenient at night, although everyone is very good tempered, and complaints are reduced to a minimum."

Lieut. Beaumont's party was accompanied by Dr. Coppinger till May 4, and Beaumont says :-

"It was at the end of this journey, May 6 , that J. Hand, A.B., one of my sledge crew, told me in answer to my inquiry as to why he was walking lame, that his legs were becoming very stiff, he had spoken to Dr. Coppinger about them, but attributing the stiffness and soreness then to several falls that he had had, he did not think much of it, before that officer's departure ; now, however, there was pain as well as stiffness, and both were increasing. I directed him to use liniment before he turned in, which he afterwards said made him better."

This was the first beginning of scurvy, but even a medical officer attached to the expedition had obviously supposed it the mere common swollen leg and ankle of ordinary Arctic sledging. Beaumont goes on :-

"On coming into camp I examined Hand's legs, and found the thighs discoloured in patches, and from his description of the stiffness and pain I suspected scurvy. $I$ had no reason to expect it, indeed I had never thought of $i t$, but the striking resemblance of the symptoms to the ones described in the voyage of the Fox, as being those of Lieut. Hobson, who suffered severely from scurvy, suggested it to my mind, and my suspicions were confirmed by Gray, the captain of my sledge, an ice quartermaster, who, in his whaling experience, has seen much of it. $\mathrm{He}$, however, led me to believe, at the same time, that it would probably wear off, saying that many of the men in whale ships who have it lying "twixt the flesh and the bone all the winter,' as he expressed it, wear it off by the regular exercise and work of their occupation when the spring comes; it was a good sign, he said, that it should come to the surface. Thus, from the 7 th until the Ioth I waited, hoping that his words might prove true. I was very reluctant to order Lieut. Rawson to return, it was like sending back half the party; it would be, I felt, a great disappointment to him to turn back then, and his advice and assistance would be a very great loss to me, but the indications of the disease and their aggravated nature became too plain to be misunderstood-sore and inflamed gums, loss of appetite, \&c., all pointed too clearly to scurvy; so on May Io it was arranged that Lieut. Rawson, with his party, should take Hand back, deciding, on his arrival at Repulse Harbour, whether to cross over to the Alert or go on to Polaris Bay. I at the same time called upon the remainder of my men to say honestly if they suspected themselves to be suffering from the same disease, or could detect any of its symptoms, as in that case it would be better for the party to advance reduced in numbers than to be charged with the care of sick men. I did this because two of them had complained of stiff legs after the hard work on the snow slopes, but they all declared themselves to be now perfectly well, and most anxious to go on."

So much for the scurvy question. The Blue-Book makes it manifest that neither the commanders of the sledge parties nor Captains Nares and Stephenson, nor Dr. Coppinger suspected that the sledge parties would be in danger of that terrible disease.

The most interesting part of the story is told in the daily journals kept by Markham, Aldrich, and Beaumont. No reader of these simple and modest records will doubt that "the ancient spirit is not dead" which has carried the Union Jack in triumph over every ocean, and planted it wherever honour and danger were most surely to be found.

Markham and Aldrich left the Alert on April 3, tra* 
velling in company to Cape Joseph Henry-latitude $82^{\circ} 50$. From that point Markham struck straight north on April I r, with fifteen men and three sledges, weighing in all 6,079 lbs., or 405 lbs. $-3 \frac{3}{4}$ cwts.-per man. They carried two ice-boats with them, the first of which, weighing 740 lbs., had to be abandoned on April 19, while the second, weighing 440 lbs., their only chance of safety if the ice should break up, had to be abandoned on May 27, while they were still seven miles or so from the nearest land. The ice on the surface of the floes was covered generally with snow some three feet deep, and the men sank in it beyond their knees. If the Palæocrystic sea had been a decently level plain covered with loose powdery snow, the work to get to the pole would have been hard enough. The party found it much such a place as South Kensington might be after an earthquake had toppled half the houses into ruin. There was seldom a floe or flat ice-surface of any extent-rarely as much as a mile in any direction - never more than a mile and three-quarters. "For the last ten or fifteen days of our outward journey," says Markham, "floes were few and far between, and it might almost be said that our road lay entirely through hummocks and deep snow-drifts." A hummock is a huge mass of ice-blocks piled up like builder's rubbish. The highest mass measured was 43 feet 2 inches, but many were observed which exceeded that height, and were estimated as between 50 and 60 feet. On the heavier floes were high hillocks apparently formed by snow drift, the accumulation probably of years, resembling diminutive snow mountains, and varying from 20 to over 50 feet in height. It was across this sort of material that the party had to drag themselves to the pole. They found that they could scarcely ever get along without "double banking." They had two sledge crews for three sledges, and they had calculated to pull the heavy sledge by the whole fifteen men, and to return for the lighter sledges which were to come up together, each dragged by its seven or eight men. Thus three miles of ground would have had to be traversed for every mile made good. In fact even the smaller sledges needed almost always the whole fifteen men, and after the larger ice-boat was abandoned on April r 9 th, there was little difference of weight between them. Thus each mile in advance cost five miles walking, three of them full loaded, two through the snow and without the steadying support of the drag-ropes. The back journeys were found almost as fatiguing as the others. From April 16th (Cape Joseph Henry) to May 12th, the most strenuous efforts carried them from $82.49 \frac{1}{2}$ to 83.20 .26 , i.e. 31 minutes northing, or about thirtysix English miles in twenty-six days, an average of $\mathrm{i}$ miles a-day advanced, and of seven miles walked. The advance was soon impeded by the illness of the men. It is on the 14 th-eleven days from the ship, three days from the depot and last land at Cape Joseph Henry - that we first find the ominous entry, "pain in his ankle and knee, both of which exhibited slight symptoms of puffiness." On the I6th the patient had to be put on one of the sledges, so that already there were only fourteen men at the drag-ropes and $x$ 6olbs. more to drag. "On the I7th another man cannot drag but is just able to hobble after us," carrying, that is to say, his own weight, but only for half the day. On the reth both had to be carried, and another man fell out from the drag-ropes. Although they dropped their ice-boat, 740 lbs. weight, on the I9th, on the $25^{\text {th }}$ a fourth man is reported weak. A fifth man "can scarcely walk" on May 2nd, and on May 3 rd all five are "utterly helpless and therefore useless." On May 4th "more of the men are complaining of stiffness and pain in their legs, which we fear are only the premonitory symptoms." Here is a glimpse of the party on May 6th :-

"The sick men are invariably the cause of great delay in starting, as they are perfectly helpless, being even unable to dress or undress without assistance. We appear to have arrived at a perfect barrier of hummocks and portions of floes, all broken and squeezed up and covered with deep snow. It is possible we may be able to penetrate these obstacles, eventually reaching larger and more level floes, on which we may be able to make more rapid progress. We ascended one large hummock, from the summit of which the prospect was anything but encouraging-nothing but one vast illimitable sea of hummocks. The height of this hummock was ascertained by means of a lead line, and was found to be from its summit to the surface of the snow at its base 43 feet 3 inches. It did not appear to be a floe-berg, but a mass of hummocks squeezed up and cemented together by several layers of snow, making it resemble one huge solid piece. The travelling has been exceedingly heavy, and with the weights on the sledges augmented, the deep snow, and a third of our band hors de combat, it is next to impossible to advance many feet without resorting to 'standing pulls,' or the endless 'one, two, three, haul."'

On the $7^{\text {th }}$ they had to "advance with one sledge, unload it, return with it empty, and then bring on the gear and invalids." On the 8 th " the interior of our tents have more the appearance of hospitals than the habitations of strong working men. In addition to the cripples, four men are suffering from snow blindness." It is in this condition that they struggle through the sea of hummocks.

"The hummocks around us are of different heights and bulk, varying from small fragments of ice to huge piles over 40 feet high. Some of these larger ones are simply masses of squeezed-up ice, whilst others of great magnitude, but perhaps not quite so high, are the regular floe-bergs. Between these hummocks, and consequently along the only road that is practicable for our sledges, the snow has accumulated in drifts to a great depth, and these forming into ridges render the travelling all the more difficult. Some of the tops of these ridges are frozen hard, and it is no uncommon occurrence to step from deep snow through which we are floundering up to our waists, on to a hard frozen piece, and vice versâ. Occasionally these ridges are only partially frozen, suffi ciently only to deceive one, which makes it exceedingly disagreeable and laborious to get through."

On May ro, "with five out of our little force totally prostrate, four others exhibiting decided symptoms of the same complaint," Commander Markham sees that it would be "folly to persist pushing on." They have been forty days out and are only provisioned for thirty more. On the i2th those left decently strong go out in the morning for their farthest north-I $-1 \frac{1}{2}$ miles out from the camp, $399 \frac{1}{2}$ from the pole. There they sang the "Union Jack of Old England," the "Grand Palæocrystic Sledging Chorus," winding up, like loyal subjects, with "God save the Queen." When they got back to the sledge they broached a magnum of whisky sent for the purpose by a genial and henceforth famous ecclesiastical potentate, "the Dean of Dundee," smoked a single cigar apiece, presented them ad hoc before leaving the ship, and 
consumed the solitary hare they had shot on the way out. The story of their return journey is intensely interesting. On June 7 , when they had still forty miles to go, and doubtless were near the end of their provisions, Lieut. Parr-whose untiring energy and admirable "road-making" made him the very perfection of companions for Commander Markham-started alone on a desperate walk to the ship for assistance. They had only eleven good legs out of thirty four in the party, and "even some of these are shaky," says Markham on May 25. Fortunately two of them, both excellent, remained to Parr a fortnight later. The first death of the party happened next day, but the day after, June 9, late in the evening, relief came. Parr's wonderful walk-far more memorable than Weston's or O'Leary's-probably saved the lives of one or two men of the gallant party which has come nearest of any human being, possibly nearest of ariy living creature, to the solitude of the North Pole.

Space alone prevents us dwelling on the equally interesting work done by Aldrich on the northern shore of the American continent, and by Beaumont on North Greenland. The names of Markham, Aldrich, Beaumont, Parr, and Sir George Nares, have been added definitively to the long list of our Arctic heroes. Few things have been finer in seamanship than Sir George Nares' passage up Smith's Sound and Robeson Channel into the Palæocrystic sea and home again. The skill with which he devised and combined the exploring parties and prepared everything so that the utmost was accomplished which it was possible for brave men to accomplish without useless sacrifice of human life, has scarcely yet received sufficient acknowledgment either from his country or from the public.

\section{ANTHRACEN}

Anthracen; its Constitution, Properties, Manufacture, and Derivatives, including Artificial Alizarin, Anthrapurpurin, Eoc., with their Applications in Dyeing and Printing. By G. Auerbach. Translated and edited by William Crookes, F.R.S, (London: Longmans, Green, and Co., I877.)

FROM the extent to which the anthracene and arti. If ficial alizarin industries have grown within the last few years, and the interest taken in them in England, it has been deemed advisable to bring forward an English edition of Auerbach's text-book on the above subject. This work has been carried out by Mr. W. Crookes, from a revised manuscript supplied by the author.

In the author's preface to this volume we are told that since the production of the first German edition four years ago, from the amount of new facts recently brought to Jight, it has been found necessary to make various additions, so as to render the treatise complete up to the present date. The arrangement of the earlier edition has been to a certain extent adhered to, but made rather more systematic, placing certain of the compounds in groups to admit of easy reference.

At the commencement a short account of anthracene is given, and reference made to the first investigations of 'the body, by Dumas and Laurent in 1832 , and the later discoveries of Fritzsche, Anderson, Berthelot, Graebe, and Liebermann, with some remarks on the views entertained by these two latter chemists, with regard to the constitution of anthracene and its derivatives. After describing the physical properties of this body, and the different modes in which it may be formed, a full description is entered into of its manufacture on a large scale, from coal tar, according to the results obtained by E. Kopp, who has made a careful study of the preparation of anthracene from soft pitch. A description is also given of the furnace best adapted for the distillation of the pitch, and the different methods for purifying the crude anthracene by extraction with heavy naphtha, and sublimation.

In treating of the methods for the valuation of crude anthracene, the older processes in which it may be extracted by means of alcohol or carbon disulphide are mentioned, from their having to a certain extent an historical interest, but which have been superseded by the method of Luck, in which greater accuracy is obtained. This latter method depends on the conversion of anthracene into the theoretical quantity of anthraquinon when dissolved in glacial acetic acid and boiled with chromic acid. A full description is given of the hydrides of anthracene, and its chlorine and bromine derivatives. In the description of anthraquinon, before entering upon its properties and manufacture, the various methods in which it may be synthetically formed are discussed, among others, the method of Bayer and Caro, by means of which the anthraquinon derivatives may be formed from phthalic acid and phenolene; the discovery of which method has added much to a clearer conception of the nature of anthraquinon.

The latter half of the volume deals with the history and preparation of natural and artificial alizarin, and the consideration of its derivatives. In describing the different processes for the preparation of artificial alizarin, mention is made of the improvement on former methods introduced by Graebe, Liebermann, and Caro, in which they produce it from monosulphanthraquinonate of soda; the advantage claimed by these over the other methods being the direct conversion of anthracene into bisulphanthracenic acid, and its transformation into bisulphanthraquinonic acid by cheap oxidising agents.

Anthraflavic acid, chrysammic acid, purpurin and their derivatives receive full consideration, and an appendix is attached containing some practical receipts for dyeing with purpurin and artificial alizarin.

The volume concludes with a most valuable bibliography embracing a list of the substances treated of throughout the work arranged in alphabetical order, with the names of the authors who have written on that particular branch of the subject, and with exact reference to the journals in which the researches have been published. As papers on the different subjects mentioned in the volume are scattered over many different periodicals, the completeness with which this bibliography has been arranged will prove a most valuable assistance to those who wish to consult the original memoirs.

We observe that throughout the edition Mr. Crookes has retained the German mode of writing anthracene without the final " $\mathrm{e}$ "; this may be unimportant, but it is not the method usually adopted in English text-books. There is a slight mistake at the top of page 157 in the use of the term "ferrous" instead of "ferric." This is 